\title{
Implementation of the Whole Language in Hong Kong Kindergartens: The Teachers' Perceptive
}

\author{
Pui Lee Liu \\ Department of Chinese Language Studies, Hong Kong Institute of Education, Hong Kong, China \\ Email: plliu@ied.edu.hk
}

Received January $8^{\text {th }}, 2013$; revised February $23^{\text {rd }}, 2013$; accepted March $3^{\text {rd }}, 2013$

\begin{abstract}
Copyright (C) 2013 Pui Lee Liu. This is an open access article distributed under the Creative Commons Attribution License, which permits unrestricted use, distribution, and reproduction in any medium, provided the original work is properly cited.
\end{abstract}

\begin{abstract}
The whole language approach is an important language theory in the West. In recent years, many kindergartens in Hong Kong have been implementing the whole language approach. To understand how this western educational concept is being implemented in the Chinese society, this research aims to investigate the current practices of teachers implementing the Whole Language Approach in Hong Kong. The study employed a combination of quantitative and qualitative methods with data collected through questionnaires and interviews. 138 questionnaires were sent to experienced teachers. A total of six teachers were interviewed, and they were all experienced. Findings indicate that most of the kindergarten teachers have the basic understanding of the whole language approach. However, it finds that many teachers cannot fully implement the meaning of the whole language approach in it entirely. Further training for teachers is needed.
\end{abstract}

Keywords: Whole Language Approach; Kindergarten; Portfolio; Language Environment

\section{Introduction}

In recent years, many kindergartens in Hong Kong have been implementing the whole language teaching approach, in order to nurture children in a rich and excellent language environment at an early age, cultivate their interests in language learning and lay a foundation for them to learn language in a better way. How do kindergarten teachers (hereinafter referred to as "teachers") in Hong Kong implement this western educational concept of whole language approach in the prevailing Chinese society? Having worked as a teacher educator for years, there have been many occasions for me to visit kindergartens and observe how teachers implement the whole language approach. Based on my personal experience, there are some characteristics that can be commonly found in Hong Kong kindergartens. These include the rich learning environment, the large number of language activities and the use of portfolios. However, the question is whether the above practices can fulfill the philosophy of the whole language approach. What are teachers' perspectives and comments? This research aims to investigate the current practices of teachers implementing the whole language approach in Hong Kong. Based on the findings, it is hoped that this research would be able to provide some inspirations for teachers.

\section{Literature Review}

\section{What Is Whole Language?}

Whole language was viewed as an important language theory in the West in the 1980s, influencing early childhood education in almost the entire world. It can be interpreted in many different ways (Bergeron, 1990). Some researchers (Cornett \&
Blankenship, 1990; Trenholm, 1992) define whole language by comparing a traditional and a whole-language classroom and looking at how practices differ. But the definition given by Goodman (1986), Father of the Whole Language Approach, is the most well-known. He suggested that whole language education is a way of thinking in which children's language development and learning are considered as a whole. He calls it "a way of bringing together a view of language, a view of learning, a view of people" (p. 5). It is neither pedagogy, nor a measure, but a faith, an attitude and a philosophy related to learning and teaching of language and curriculum. As whole language is not pedagogy, there are no distinct steps for teachers to follow, so they may have difficulty in understanding the concept. As such, many scholars have tried to analyse the characteristics of whole language from different perspectives.

From the language learning perspective, the traditional approach to learning language has been to begin with small parts and build toward larger units of language; children learn language from fragments such as articulation or individual words, and thus, many teachers focus on cultivation of children's verbal ability. Whole language approach begins by presenting the whole and then helping the students master its parts as need dictates (Myers, 1993). "Whole" in Whole Language means "completeness", emphasising on the importance of unity (Yu \& Jia, 2008; Li \& Sun, 2009; Wang, 2009). Listening, speaking, reading and writing are indispensible and interrelated. Children do not learn language from fragments such as articulation or individual words, so the focus is not only on cultivation of verbal ability, but to carry out reading, listening, speaking and writing activities.

It is preferable that children learn in a real and meaningful language environment. Children often engage in reading the en- 
vironmental print before they can read what is printed in books (Aldridge \& Rust, 1987; Hall, 1985; Wepner, 1985; Wu \& Huang, 1987; Clay, 1991). Reading and understanding the meaning of environmental prints implies that children understand what a printed matter conveys and its meaning and functions. Teachers should let students learn in the environment where language can be used ( $\mathrm{Li}, 2007)$, rather than requiring them to acquire fragmented language skills on their own. Therefore, teachers should open up opportunities for children to use their language skills. Children may even create their own wordings for their writing (Ferreiro \& Teberosky, 1982).

In respect of the creation of a learning environment, the traditional classroom lacks a language-rich environment for children while whole language classrooms emphasize children's learning under conditions, which are real, comfortable, diversified, interesting and pressure-free (Yu \& Jia, 2008). Children's everyday surroundings are full of interesting words, so they can learn from a real language environment (Lems, 1995). The whole language teachers emphasize a print-rich environment, relating children's lives to their learning. Thus, teachers should provide a more print-rich environment for children to interact with and they should often show the value of print to share meaning in discussion (Yoo, 1996).

From the teaching perspective, the traditional approach is quite teacher-center while the whole language approach is more student-center. The whole language teachers become facilitators of learning rather than instructors who use control and authority in traditional teaching (Yoo, 1996). In whole language classrooms, teachers organise listening, speaking, reading and writing activities in accordance with different thematic units. The practice above is interdisciplinary in nature, emphasising that the course content is meaningful, communicative and practical. Meanwhile, learning activities are student-oriented and designed according to their interests and wishes. Therefore, students can enjoy a substantial degree of autonomy and right of choice (Yu \& Jia, 2008). The children themselves, rather than the teachers, own their learning process (Lee \& Lin, 2007). The Whole Language approach also pays strong attention to student-teacher interactions, unlike the concept of "Given by Teachers, Received by Students." These classrooms focus on students' learning from their cooperation with teachers (Wang, 2006) and their interactions with teachers and classmates. Activities, that are not of interest, such as spelling and copying, are rejected by the whole language approach (Moorman, Blanton, \& McLanughlin, 1994).

In respect of learning assessment, the traditional approach always emphasizes product measures, based on assessments of children's skills by tests and examinations, after they have learnt (Froese, 1996) while the whole language approach focuses on assessing the process of how children learn. Teachers usually use alternative assessment methods so that they can collect growth artefacts for children. For example, in whole language approach, teachers observe and record children's performance in class (Heald-Taylor, 1989) and guide them to conduct selfassessment and peer assessment, produce audio-visual media records and develop portfolios, etc. Myers (1993) suggested that the preferred form of assessment in whole language classrooms seems to be the portfolio. It not only includes samples of students' works, which show the depth and breadth of knowledge, but also includes other measures such as observation checklists, conducting interviews and reviews of previous records. Portfolios can capture children's growth and their personal meanings (Engel, 1993). It supports and honors both process and products of learning as well as formal and informal measures of learning (Enoki, 1992).

\section{Related Researches}

In western countries, there has been much debate on the whole language approach from the education perspective. Scholars who support the concept of whole language, such as Goodman (1986), believe that children's language learning ability is inherent. Under a real language situation, with only limited language stimulation provided, children can easily and rapidly develop their oral language skills. The same applies to written language. Scholars who oppose the concept of whole language believe that reading ability is not inherent; it is something that should be learnt with great effort (Liberman, Shankweiler, \& Liberman, 1989). Many researchers (such as Jeyne \& Littell, 2000; Juel \& Minden-Cupp, 2000) have also questioned the teaching effectiveness of whole language in case of less able students. Nevertheless, overall, researchers have a relatively positive attitude toward implementation of the concept of whole language in kindergartens. Some studies have discovered that whole language can increase children's readiness, significantly improve their word recognition ability and develop a good reading attitude (Stahl, Mckenna, \& Pagnucco, 1994). Some other researchers point out that applying whole language in kindergartens is more effective than in primary schools (Primary 1 students) because basic reading and writing concepts can be better transferred in case of the former (Stahl \& Miller, 1989). Therefore, its implementation of whole language has been more successful in kindergartens.

In Asia, there have been some research studies, especially in Taiwanese kindergartens and primary schools, concerning the use of the whole language approach. Ho (1997) pointed out that students were interested in learning Chinese language lessons. The class atmosphere was improved and so was their understanding of Chinese culture. However, Shih (1990) indicated that some negative factors existed such as the increase of administrative matters, deficiency in teaching discussions and defects in portfolio assessment.

In Hong Kong, only a few researchers have studied implementation of whole language in kindergartens. Lam and $\mathrm{Au}$ (2006) mainly explored the effectiveness of whole language learning in kindergartens and pointed out some existing problems. Their research was based on a group of upper kindergarten students. At present, there is no published study adopting quantitative and qualitative approaches to investigate the current situation of Hong Kong teachers who are implementing whole language approach. In view of this, this research attempts to explore this aspect more.

\section{Aims and Methodology}

The research questions are:

1) How do teachers implement the concept of whole language approach in kindergartens?

2) What are the comments of teachers when implementingwhole language approach?

The study employed a combination of quantitative and qualitative methods, with data collected through questionnaires and interviews. It was a kind of mixed method design. Both quantitative and qualitative methods were used so as to increase the 
scope and comprehensiveness of the study. Quantitative study can help interpret the general data in the study, providing explanations for the findings. Supplementary data from qualitative study may provide different information or insights as to what is happening in the data (Morse, 2003). It is then easier to better understand research questions by converging numeric trends from quantitative data and specific details from qualitative data (Hanson et al., 2005). Both methods are used sequentially with a deductive theoretical drive.

Questionnaires were sent to experienced kindergarten teachers who were in-service teachers and samples were selected from students studying a Higher Diploma in Early Childhood Education Programmein the semester of academic year 2009-10 at the Hong Kong Institute of Education. These students had already been qualified as kindergarten teachers before taking the programme. They joined the programme mainly for the purpose of staff development. Meanwhile, the kindergartens they are teaching at have already implemented the Whole Language approach.

Some part of content of the questionnaire was based on the whole language checklist designed by Bird (1994). Two experienced teacher educators (researchers) discussed the checklist, selected the items of "Learning in a social environment" and "Language Development" and re-designed the items in the questionnaires such that they became suitable for learning Chinese language. The content of the questionnaire included three parts. Part one was personal particulars, part two was the Five Points Scale of the current practice of whole language approach and teachers' perspectives and part three was the column where teachers freely wrote their comments.

A total of six teachers selected by random sampling were interviewed. They were all experienced teachers who had answered the questionnaires. All the interviews were tape-recorded. Open-ended interview questions were as follows:

1) How do you help children learn in the whole language approach?

2) How do you assess children's learning in the whole language approach?

3) What are your comments on implementing the whole language approach?

\section{Results and Discussion}

The quantitative approach is based on questionnaires. 138 sets of the questionnaire were distributed and 122 answered sets were received. The return rate is $88 \%$. Teachers who filled in the questionnaires are teaching at different kindergartens with different lengths of teaching experience (refer to Table 1). Many of them are experienced teachers, so their responses are representative to a large extent.

This research is also based on interviews with six teachers. They are teaching at different schools with experience of five

Table 1.

Teaching experience of teachers.

\begin{tabular}{cc}
\hline No. of years & Percentage \\
\hline $1-5$ years & $4.1 \%$ \\
$6-10$ years & $14.8 \%$ \\
$11-15$ years & $38.5 \%$ \\
$16-20$ years & $34.4 \%$ \\
21 years or above & $8.2 \%$ \\
\hline
\end{tabular}

years or above. These teachers have considerable knowledge of teaching, so they can provide this research with in-depth and accurate information. Codes T1, T2, T3, T4, T5 and T6 are used to represent the six interviewees when their comments are quoted.

1) A learning language environment is created but functions of environmental print are not thoroughly being achieved.

Table 2 shows that many teachers $(69.7 \%)$ often and always create a learning language environment for children. Performance of teachers in this respect is good. Firstly, they label words in classrooms. Most of the teachers $(88.5 \%)$ put down the name on the Activity Corner, while almost $60 \%$ label objects in the Corner. Secondly, teachers put books in classrooms. Most of the teachers $(92.7 \%)$ put books in the Book Corner for students to read. It is commendable that most teachers (90.1\%) agree they should regularly renew classrooms' decor and books in the Book Corner $(83.6 \%)$. This shows that teachers are not static when creating a learning language environment for children.

Therefore, slogans such as "Wash your hands before eating!" should be used to ask children to recognise words but they should not be designed by teachers on their own. Teachers should discuss and create (including pictures and written symbols) them jointly with their students. More importantly, children can understand the functions of words. The function of the slogan above is to remind children to wash hands before eating. Teachers and children producing slogans together, with communication and interaction, can cultivate students' sensitivity to words and pictures they come across together, and increase their understanding of functions of language and words.

To conclude, many teachers can create a learning environment for children by creating decorations, labeling words and having book corners in the classrooms where children can learn in a real, diversified and interesting environment, as $\mathrm{Yu} \& \mathrm{Jia}$ (2008) mentioned. However, teachers should provide more opportunities for children to interact with the print-rich environment, share and discuss the value of print, as suggested by Yoo (1996). Teachers and children should decorate the classrooms together and communicate naturally under a language-rich environment so that they can gradually develop certain abilities related to usage of written symbols and understand the functions of prints. Then they shall have more interest in learning language(s) from their surroundings.

2) A large number of language activities (reading, listening, writing and speaking) are carried out. Most of them are in line with the concept of whole language. However, those related to children's mechanical copying activities are in contradiction with the whole language approach.

Table 3 shows that most of the teachers $(83.5 \%)$ read story books together with children, in order to cultivate children's listening, speaking, reading and writing ability by storytelling. Some teachers provide children with a large number of language learning activities (59\%) and opportunities to use language $(65.6 \%)$.

Some teachers mentioned that these activities are based on children's interest, mostly related to reading and storytelling, and are associated with many extended activities. If the course content of the same thematic unit is designed according to the interests of children in each class, interdisciplinary activities such as playing and singing, making handiworks and conducting little scientific experiments can be carried out.

It is commendable that there is much interaction in reading activities. Table 3 shows that interactions include teachers shar- 
Table 2.

Creating an environment for language learning.

\begin{tabular}{|c|c|c|c|c|c|c|}
\hline \multirow{2}{*}{ Items } & \multicolumn{5}{|c|}{ No. of respondents (Percentage) } & \multirow{2}{*}{ Standard deviation (S.D.) } \\
\hline & 1 & 2 & 3 & 4 & 5 & \\
\hline Teachers create an environment for language learning & $\begin{array}{c}0 \\
(0 \%)\end{array}$ & $\begin{array}{c}1 \\
(.8 \%)\end{array}$ & $\begin{array}{c}36 \\
(29.5 \%)\end{array}$ & $\begin{array}{c}66 \\
(54.1 \%)\end{array}$ & $\begin{array}{c}19 \\
(15.6 \%)\end{array}$ & $\begin{array}{l}3.84 \\
(.68)\end{array}$ \\
\hline Putting down the name on the Activity Corner & $\begin{array}{c}0 \\
(0 \%)\end{array}$ & $\begin{array}{c}0 \\
(0 \%)\end{array}$ & $\begin{array}{c}14 \\
(11.5 \%)\end{array}$ & $\begin{array}{c}31 \\
(25.4 \%)\end{array}$ & $\begin{array}{c}77 \\
(63.1 \%)\end{array}$ & $\begin{array}{l}4.52 \\
(.69)\end{array}$ \\
\hline Labeling objects in the Activity Corner & $\begin{array}{c}3 \\
(2.5 \%)\end{array}$ & $\begin{array}{c}6 \\
(4.9 \%)\end{array}$ & $\begin{array}{c}39 \\
(32 \%)\end{array}$ & $\begin{array}{c}53 \\
(43.4 \%)\end{array}$ & $\begin{array}{c}20 \\
(16.4 \%)\end{array}$ & $\begin{array}{l}3.67 \\
(.90)\end{array}$ \\
\hline Putting books in the Book Corner & $\begin{array}{c}0 \\
(0 \%)\end{array}$ & $\begin{array}{c}2 \\
(1.6 \%)\end{array}$ & $\begin{array}{c}7 \\
(5.7 \%)\end{array}$ & $\begin{array}{c}18 \\
(14.8 \%)\end{array}$ & $\begin{array}{c}95 \\
(77.9 \%)\end{array}$ & $\begin{array}{l}4.69 \\
(.66)\end{array}$ \\
\hline Renewing books in the Book Corner & $\begin{array}{c}0 \\
(0 \%)\end{array}$ & $\begin{array}{c}3 \\
(2.5 \%)\end{array}$ & $\begin{array}{c}16 \\
(13.1 \%)\end{array}$ & $\begin{array}{c}45 \\
(36.9 \%)\end{array}$ & $\begin{array}{c}57 \\
(46.7 \%)\end{array}$ & $\begin{array}{l}4.29 \\
(.79)\end{array}$ \\
\hline Teachers share the decorations with children & $\begin{array}{c}0 \\
(0 \%)\end{array}$ & $\begin{array}{c}13 \\
(10.7 \%)\end{array}$ & $\begin{array}{c}45 \\
(36.9 \%)\end{array}$ & $\begin{array}{c}49 \\
(40.2 \%)\end{array}$ & $\begin{array}{c}15 \\
(12.2 \%)\end{array}$ & $\begin{array}{l}3.32 \\
(.87)\end{array}$ \\
\hline Teachers always decorate classrooms on their own & $\begin{array}{c}2 \\
(1.6 \%)\end{array}$ & $\begin{array}{c}5 \\
(4.1 \%)\end{array}$ & $\begin{array}{c}42 \\
(34.4 \%)\end{array}$ & $\begin{array}{c}59 \\
(48.4 \%)\end{array}$ & $\begin{array}{c}13 \\
(10.7 \%)\end{array}$ & $\begin{array}{l}3.63 \\
(.79)\end{array}$ \\
\hline Teachers always renew classroom decorations & $\begin{array}{c}0 \\
(0 \%)\end{array}$ & $\begin{array}{c}2 \\
(1.6 \%)\end{array}$ & $\begin{array}{c}10 \\
(8.2 \%)\end{array}$ & $\begin{array}{c}67 \\
(54.9 \%)\end{array}$ & $\begin{array}{c}43 \\
(35.2 \%)\end{array}$ & $\begin{array}{l}4.24 \\
(.66)\end{array}$ \\
\hline
\end{tabular}

Note: (1: never; 2: rarely; 3: sometimes; 4: often; 5: always).

Table 3.

Language activities of children.

\begin{tabular}{|c|c|c|c|c|c|c|}
\hline \multirow{2}{*}{ Items } & \multicolumn{5}{|c|}{ No. of respondents (Percentage) } & \multirow{2}{*}{ Standard deviation (S.D.) } \\
\hline & 1 & 2 & 3 & 4 & 5 & \\
\hline Read story books with children & $\begin{array}{c}0 \\
(0 \%)\end{array}$ & $\begin{array}{c}1 \\
(.8 \%)\end{array}$ & $\begin{array}{c}13 \\
(10.7 \%)\end{array}$ & $\begin{array}{c}72 \\
(54 \%)\end{array}$ & $\begin{array}{c}36 \\
(29.5 \%)\end{array}$ & $\begin{array}{l}4.17 \\
(.64)\end{array}$ \\
\hline Provide children with learning activities & $\begin{array}{c}1 \\
(.8 \%)\end{array}$ & $\begin{array}{c}6 \\
(4.9 \%)\end{array}$ & $\begin{array}{c}43 \\
(35.2 \%)\end{array}$ & $\begin{array}{c}60 \\
(49.2 \%)\end{array}$ & $\begin{array}{c}12 \\
(9.8 \%)\end{array}$ & $\begin{array}{l}3.62 \\
(.76)\end{array}$ \\
\hline Provide children with opportunities to use language & $\begin{array}{c}2 \\
(1.6 \%)\end{array}$ & $\begin{array}{c}2 \\
(1.6 \%)\end{array}$ & $\begin{array}{c}37 \\
(30.3 \%)\end{array}$ & $\begin{array}{c}66 \\
(54.1 \%)\end{array}$ & $\begin{array}{c}14 \\
(11.5 \%)\end{array}$ & $\begin{array}{l}3.73 \\
(.75)\end{array}$ \\
\hline Children have writing activities & $\begin{array}{c}12 \\
(9.8 \%)\end{array}$ & $\begin{array}{c}14 \\
(11.5 \%)\end{array}$ & $\begin{array}{c}38 \\
(31.1 \%)\end{array}$ & $\begin{array}{c}39 \\
(32.0 \%)\end{array}$ & $\begin{array}{c}19 \\
(15.6 \%)\end{array}$ & $\begin{array}{c}3.32 \\
(1.16)\end{array}$ \\
\hline Children copy new words & $\begin{array}{c}20 \\
(16.4 \%)\end{array}$ & $\begin{array}{c}12 \\
(9.8 \%)\end{array}$ & $\begin{array}{c}20 \\
(16.4 \%)\end{array}$ & $\begin{array}{c}38 \\
(31.1 \%)\end{array}$ & $\begin{array}{c}32 \\
(26.2 \%)\end{array}$ & $\begin{array}{c}3.41 \\
(1.40)\end{array}$ \\
\hline Children share their feeling with children & $\begin{array}{c}1 \\
(.8 \%)\end{array}$ & $\begin{array}{c}5 \\
(4.1 \%)\end{array}$ & $\begin{array}{c}25 \\
(20.7 \%)\end{array}$ & $\begin{array}{c}68 \\
(55.7 \%)\end{array}$ & $\begin{array}{c}22 \\
(18 \%)\end{array}$ & $\begin{array}{l}3.87 \\
(.79)\end{array}$ \\
\hline Teacher share their feeling with children & $\begin{array}{c}0 \\
(0 \%)\end{array}$ & $\begin{array}{c}2 \\
(1.6 \%)\end{array}$ & $\begin{array}{c}23 \\
(18.9 \%)\end{array}$ & $\begin{array}{c}62 \\
(50.8 \%)\end{array}$ & $\begin{array}{c}35 \\
(28.7 \%)\end{array}$ & $\begin{array}{l}4.07 \\
(.74)\end{array}$ \\
\hline Children share the content of the book with children & $\begin{array}{c}1 \\
(.8 \%)\end{array}$ & $\begin{array}{c}10 \\
(8.2 \%)\end{array}$ & $\begin{array}{c}54 \\
(44.3 \%)\end{array}$ & $\begin{array}{c}46 \\
(37.7 \%)\end{array}$ & $\begin{array}{c}11 \\
(9 \%)\end{array}$ & $\begin{array}{l}3.46 \\
(.80)\end{array}$ \\
\hline Teacher share the content of the book with children & $\begin{array}{c}0 \\
(0 \%)\end{array}$ & $\begin{array}{c}1 \\
(.8 \%)\end{array}$ & $\begin{array}{c}36 \\
(29.5 \%)\end{array}$ & $\begin{array}{c}68 \\
(55.7 \%)\end{array}$ & $\begin{array}{c}16 \\
(13.1 \%)\end{array}$ & $\begin{array}{l}3.82 \\
(.66)\end{array}$ \\
\hline
\end{tabular}

Note: (1: never; 2: rarely; 3: sometimes; 4: often; 5: always).

ing feelings with children $(79.5 \%)$, teachers sharing story content with children $(68.8 \%)$, children sharing story content with classmates $(46.7 \%)$, children sharing feelings with classmates (73.7\%) and children having opportunities to cooperate with each other $(78.7 \%)$. These interactions can cultivate children's listening and speaking abilities.

Teachers are able to design writing activities for children (47.6\%) (refer to Table 3). From the interviews with teachers, writing activities can be divided into two types. On the one hand, teachers can help children convert their spoken words into written words. On the other, children can write words on their own even if they use pictures. Here are the examples:

Teachers can write sentences related to the theme or put down useful sentences spoken by children on the white board. If children like any of these sentences, they make their own sen- tences according to the samples. As children can create these sentences with the help of teachers, they are very happy! (T5)

Every child makes a mail box. If children want to write letters to other children, they will convert their ideas into words or pictures, and then put the letter into an appropriate mailbox. If they do not know how to write a certain character, they will look up their textbooks or booklets, which are used to collect words and phrases. After that, they can follow the strokes on the textbooks or booklets and write the characters. I let them check their mailbox every day or every week, in order to collect and share their letters. (T6)

However, it should be noted that more than half of children $(57.3 \%)$ are given exercises in which they copy new words. An interviewee mentioned that:

In the course of writing exercises, drawing is used for lower 
class children, so as to train their little muscles. In the second term, they start to write by imitating the shape of the character. They are also asked to copy new words in Upper class. (T1)

Drawing, writing by imitating the shape of the character and picture writing are all in line with the concept of whole language. However, mechanical copying activities are not in the spirit of whole language. Three teachers (half of the interviewees) showed that their schools require children to do many copying exercises in order to accommodate parents' needs. Parents request this because they want their children to learn more words and to have more advantages when promoted to Primary 1. However, do mechanical copying activities mean knowing more words? This is a question that must be considered carefully by schools and parents. Moreover, many teachers ask students to copy words, it is not students' choice. Students cannot enjoy a substantial degree of autonomy which contrary to findings of Yu \& Jia (2008) and Lee \& Lin (2007) in Taiwan.

3) Teachers can use alternate assessment methods, but self and peer assessment activities for children are rare. Although many teachers use portfolios to document children's growth, some teachers query the relationship between the use of portfolios and the concept of whole language.

This research has discovered that many teachers $(86 \%)$ often observe children's performance. $77.3 \%$ of the teachers take pictures for children to record their learning situations. However, only $19 \%$ and $18.9 \%$ agree that self or peer assessment activities should be carried out for children. A teacher showed that:

Self and peer assessments are rarely adopted in language teaching, but more in arts activities. I (teacher) only ask them whether their drawings are beautiful or not. (T4)

Teachers do not let children conduct self and peer assessment because they think children are too young to do so. However, potential of children should not be underestimated. One teacher points out that if enough guidance is given to children, especially the Upper class students, they will be willing to carry out self and peer assessment activities.

This research also discovered another interesting question. Many teachers (78.7\%) use portfolios but three teachers (half of the interviewees) pointed out that there is not much relationship between portfolios and the concept of whole language. One of the teachers said that:

Portfolios and the implementation of whole language are not related. Portfolios are only products that teachers have to create for their schools... It is used for administrative purposes. What children have learnt cannot be shown in portfolios. For example, the greeting cards they make, together with the words they write, are displayed in the Creative Corner. Learning is effective, but these cards are not collected in portfolios. (T2)

Actually, this reflects that teachers do not understand portfolios thoroughly. This is consistent with results of Liu (2009), indicating many teachers cannot understand the in-depth meaning of the use of portfolio, which is a collection of children's learning artefacts and a record of their development history. It offers opportunities to exhibit the child's performance and growth over time (Kankaanranta, 1996). It can be used to form a total judgment of what is needed for the child's further growth, based on daily events of the classroom (Mills, 1994). The gathering and documentation of children's work samples should provide meaningful information data for measuring children's progress. The rationale behind developing the portfolios includes the philosophy of whole language and documentation of the child's work ensures that there is an insightful record of each child's performance (Enoki, 1992). This is one of the important assessment methods suggested by the whole language approach. The relationship between the portfolios and the whole language approach should be closely related.

4) Most teachers point out that children can learn happily in the whole language approach, however, their workload is heavy.

In respect of teachers' comments on implementing the whole language approach, this study discovered that most of the teachers $(86.1 \%)$ affirm the effectiveness of the whole language approach in kindergartens. Many of the teachers think children can handle language well $(74.6 \%)$, cultivate their own listening, speaking, reading and writing ability $(76.3 \%)$ and learn happily (85.2\%). A teacher showed that:

Implementing whole language teaching has indeed increased our workload. I have to design learning materials and activities... but when I know that children show interest in learning and they can learn happily and improve their writing, reading and speaking ability, it is worthwhile even if I have to work harder. (T3)

This finding is consistent with findings of Ho (1997) in Taiwan. He pointed out that students are interested in learning Chinese language lessons and they learn better with the whole language approach. However, both Taiwan and Hong Kong teachers face some frustration. In Taiwan, many teachers face peer pressure (Lee \& Lin, 2007), in terms of comparison, competition and reluctance to change and sometimes it even arouses fear among teachers. But in Hong Kong, teachers encounter pressure especially in terms of heavy workload, lack of storybooks, the need for preparing a large number of teaching materials and carrying out plenty of assessment work. Regarding the lack of books, this research discovered that more than $40 \%$ of teachers $(44.3 \%)$ provide children with plenty of reading materials (refer to Table 3). Some interviewed teachers (four out of six) complained that books in their schools are not enough, so they cannot provide opportunities for children to do extensive reading. They can only ask children to exchange books to read, which affects the learning effectiveness. Another teacher pointed out that contents of books vary a lot, so some parts need to be rewritten to cope with the thematic approach of the school. Sometimes teachers may write a book by themselves. As teaching materials produced by the publishers cannot cater to the needs of the children, teachers have to prepare plenty of teaching materials. They need to select books, draw pictures, compose nursery rhymes, organise self-learning activities, make handiworks and decorate classrooms, etc. Meanwhile, mostinterviewed teachers (five out of six) always need to take pictures for children, so as to capture students' learning experience and achievement for observation and records. Parents can then understand more about their children's learning in school. However, teachers' workload associated with this kind of assessment is rather heavy indeed.

\section{Implications and Conclusion}

This research indicates that most teachers in Hong Kong have the basic understanding of the concept of whole language and they are able to implement it. They have taken into account the completeness of language learning and learning activities. Listening, speaking, reading and writing activities are learneroriented. Teachers are able to create a whole language environ- 
ment for students to learn language and help children develop their own portfolios. Most teachers comment that children can learn happily.

However, this research has also found that some teachers cannot fully carry out the in-depth spiritual meaning of the whole language approach. Firstly, whole language emphasizes on functions of environmental print and cultivation of children's sensitivity to words, which are significant for the creation of a learning language environment. However, the environmental decorations are not created by teachers alone; teachers and children should have interactive activities of designing. Moreover, children's mechanical copying activities are contrary to the whole language approach. Furthermore, portfolios are one of the tools to assess children's whole language learning but teachers may not be sure how to develop children's portfolios and they have difficulties in understanding the concepts of portfolios and the whole language approach. In general, many teachers have to bear heavy workloads when using the whole language approach.

The findings suggest that teachers lack in-depth understanding of implementing the whole language approach. Thus, practical training courses and resource supports should be provided for teachers. It is suggested that educational institutions and universities can organise more teacher development courses and workshops on the topics of "Language Awareness in the environment", "Developing children's writing skills in the whole language approach" and "The use of portfolio and the Whole Language approach". The workshop sessions organized in the course should provide them with opportunities to discuss relevant issues with other teachers and this questioning and sharing can help them identify problems, evaluate their practices and learn from each other. The Hong Kong Education Bureau should provide more resources and fund for kindergartens to buy more reading materials. Also, it can recommend kindergartens with outstanding performance in implementing the whole language approach to share their experience and teaching materials on intranets so that kindergartens can support each other, which may lessen their heavy workloads.

Whole language is not an elixir which can improve children's learning in kindergartens at once. This research is only preliminary in nature. It is expected that an action research approach can be adopted in future to drill down again into the effectiveness of whole language learning of children who are promoted to Primary 1.

\section{REFERENCES}

Aldridge, J., \& Rust, D. (1987). A beginning reading. Strategy, Academic Theory, 22, 323-326.

Bergeron, B. (1990). What does the term whole language mean? Constructing a definition from the literature. Journal of Reading Behavior, 22, 301-329.

Bird, L. B., Goodman, K. S., \& Goodman, Y. M. (1994). The whole language catlog: Forms for authentic assessment. Columbus, $\mathrm{OH}$ : SRA/McGraw-Hill.

Clay, M. (1991). Becoming literate: The construction of inner control. Portsmouth, NH: Heinemann.

Cornett, C., \& Blankenship, L. (1990). Whole language $=$ Whole learning. Fastback 307. Bloomington, IN: Phi Delta Kappa Educational Foundation.

Engel, B. S. (1993). Valuing children: Authentic assessment based on observation, reflection and documentation. The New England Kindergarten Conference. Cambridege, MA.
Enoki, D. Y. (1992). Student portfolio and profiles: A holistic approach to multiple assessment in whole language. Proceeding of the Annual meeting of the American Educational Research Association. San Francisco.

Ferreiro, E., \& Teberosky, A. (1982). Literacy before schooling. Portsmouth, NH: Heinemann Educational Books.

Forses, V. (1996). Assessment: Form and function. In V. Froese (Ed.), Whole Language practice and theory (pp. 389-423). Boston, NY: Allyn and Bacon.

Goodman, K. S. (1986). What's whole in whole language? Portsmouth, NH: Heinemann.

Hall, N. (1985). When do children learn to reading, Reading, 19, 57-70.

Halliday, M. A. K. (1983). Learning how to mean. London: E. Arnold.

Hanson, W., Crewell, J., Clark, V. L. P., Petska, K., \& Crewell, J. D. (2005). Mixed methods research designs in counseling psychology. Journal of Counseling Psychology, 52, 224-235. doi:10.1037/0022-0167.52.2.224

Heald-Taylor, G. (1989). The administrator's guide to whole language. New York: Owen Publishers.

Ho, M. J. (1997) An Action Research on Implementation of Whole Language Principal for Beginners' Chinese Language Class. http://scholar.lib.ntnu.edu.tw/

Jeynes, W. H., \& Littell, S. W. (2000). A meta-analysis of studies examining the effect of whole language instruction on the literacy of low-SES students. Elementary School Journal, 101, 21-33. doi: $10.1086 / 499657$

Juel, C., \& Minden-Cupp, C. (2000). Learning to read words: Linguistic units and instructional strategies. Reading Research Quarterly, 35, 128-134. doi:10.1598/RRQ.35.4.2

Kankaanranta, M. (1996). Self-portrait of a child: Portfolios as a means of self-assessment in preschool and primary school. Childhood Education Perspectives. http://www.eric.ed.gov/PDFS/ED

Lam, C. T., \& Au, H. Y. (2006). Reflections on whole language learning in kindergarten. Hong Kong Teachers Centre Journal, 5, 1-8. doi:10.1016/S1013-7025(07)70001-5

Lems, K. (1995). Whole language and the ESL/ESL classroom. http://www.eric.ed.gov/PDFS/ED

Lee, L. J., \& Lin, W. Y. (2007). Whole language in Taiwan. In M. Taylor (Ed.), Whole language teaching, whole-hearted practice. Looking back, looking forward (pp. 137-160). New York, Washing DC: Peter Lang Company.

Li, Z. C. (2007). Whole Language: A Holistic view of Instruction. Journal of Shijiazhuang University, 1, 93-97.

Li, S. S., \& Sun, C. L. (2009). Whole language theory and its application in cultivating comprehensive language abilities. Journal of Sichuan College of Education, 3, 110-114.

Liberman, I. Y., Shankweiler, D., \& Liberman, A. M. (1989). The alphabetic principle and learning to read. In D. Shankweiler, \& I. Liberman (Eds.), Phonology and reading disability (pp. 1-33). Ann Arbor, MI: The University of Michigan Press.

Liu, P. L. (2009). Hong Kong teachers' understanding and comments on the use of children portfolios at kindergartens. New Horizon in Education, 57, 58-66.

Liu, P. L. (2011). Environmental print: Research on Hong Kong children's understanding of Chinese words. Asia-Pacific Journal of Research in Early Childhood Education, 5, 49-66.

Mills, L. (1994). Yes, it can work: Portfolio assessment with preschoolers. Proceedings from Childhood Education International Study Conference, New Orleans, LA.

Moorman, G. B., Blanton, W. E., \& McLanughlin, T. (1994). The rhetoric of whole language. Reading Research Quarterly, 29, 309-329.

Morse, J. M. (2003). Principles of mixed methods and multi-method research design. In C. Teddlie, \& A. Tashakkori (Eds.), Handbook of mixed methods in social and behavioral research (pp. 189-208). Thousand Oaks, CA: Sage Publication.

Myers, J. W. (1993). Making sense of whole language. Fastback 346. Bloomington: Phi Delta Kappa Educational Foundation.

Stahl, S. A., Mckenna, M. C., \& Pagnucco, J. R. (1994). The effects of whole language instruction: An update and reappraisal. Educational Psychologist, 29, 175-186. doi:10.1207/s15326985ep2904 1

Stahl, S. A., \& Miller, P. D. (1989). Whole language and language ex- 


\section{P. L. LIU}

perience approaches for beginning reading: A quantitative research synthesis. Review of Educational Research, 59, 87-116. doi:10.3102/00346543059001087

Shih, L. Y. (1990). The collaborative action research on whole language approach in kindergarten. http://scholar.lib.ntnu.edu.tw/

Trenholm, D. S. (1992). What is the effect of traditional language teaching method versus whole language teaching on learning sentense structure? http://www.eric.ed.gov/PDFS/ED

Wang, X. (2009). The early childhood reading under the context of whole language approach. Studies in Preschool Education, 6, 42-44.

Wepner, S. B. (1985). Linking logos with print for beginning reading success. Reading Teacher, 38, 633-639.

Yoo, S. Y. (1996). A study of how early childhood teachers' beliefs reflect their use of the whole language and traditional approaches: $A$ quantitative and qualitative analysis. Ann Arbor, MI: A Bell \& Howell Company.

Yu, L., \& Jia, F. (2008). Reconstruction, arrogation and reversion-The whole language and its limitation. Research in Teaching, 2, 143-147. 